\title{
From England to Italy: The Intriguing Story of Poli's Engine for the King of Naples
}

\author{
Salvatore Esposito*
}

An interesting, yet unknown episode concerning the effective permeation of the scientific revolution in eighteenth-century Kingdom of Naples (and Italy more generally) is recounted. The intriguing story of James Watt's steam engine, prepared to serve a Royal Estate of the King of Naples in Carditello, reveals a fascinating piece of the history of that kingdom, as well as an unknown step in the history of Watt's steam engine, whose final entrepreneurial success for the celebrated Boulton \& Watt company was a direct consequence. This story reveals that, contrary to what claimed in the literature, the first introduction in Italy of the most important technological innovation of the eighteenth century did not take place with the construction of the first steamship of the Mediterranean Sea, but rather thirty years before that, thanks to the incomparable work of Giuseppe Saverio Poli, a leading scholar and an influential figure in the Kingdom of Naples. The tragic epilogue of Poli's engine accounts for its vanishing from historical memory.

Key words: Giuseppe Saverio Poli; James Watt; Matthew Boulton; Jesse Ramsden; Kingdom of Naples; Steam engine; Carditello.

\section{Introduction}

The introduction of the steam engine in England unequivocally marked the history of industrialization in the long eighteenth century, commonly associated primarily (if not exclusively) with coal mining and factory production. James Watt emerges as a key figure, although surrounded by his predecessors and competitors who specialized in the technology that was instrumental to the development of the industrial revolution. Also crucial for such development were those people who combined technological abilities with an entrepreneurial stance in order to meet the increasing demand for machines and components used in manufacturing, mining, and infrastructural projects, who had to solve both business and technical problems. ${ }^{1}$ These abilities stimulated further innovation, enabling the adaptation of given technologies to other fields, resulting in steam engine designs and construction practices modelled on both material availabilities and informed abilities.

\footnotetext{
* Salvatore Esposito is the President of the Italian Society for the History of Physics and Astronomy. His interests involve scientists from eighteenth to twentieth centuries, focusing on the works by Giuseppe Saverio Poli and Ettore Majorana.
} 
It is important to note, however, that a significant part of the early history of steam technology had little to do with coal mining or factory production, but rather with water drainage, as well as water and land management, along with garden landscaping and milling. ${ }^{2}$ Outside Britain, the French and Dutch cases are illuminating. The marquis Antoine de Ricouart d'Herouville carried out a drainage project to pump excess water from the moors (Dunkerque) using steam power, and William Blakey's commission of the Duc of Chartres was aimed at constructing a steam-powered installation for watering his folie de Monceau. ${ }^{3}$ Also, a competition was issued by the Batavian Society concerning problems associated with adapting steam to the management of water around Rotterdam. ${ }^{4}$

The present paper reports on a different illuminating example-as yet unknown-referring to places and people who are often overlooked when studying such matters, that is the Kingdom of Naples and the Bourbon Court.

The Bourbon Kingdom of Naples was among the most important states in eighteenth century Europe, playing a unique and incomparable role for Italy and the entire Mediterranean region during the Enlightenment. As the southern Italian trading emporium, boasting an advanced banking system, Naples continued to be the third capital in Europe (after Paris and London) even after the disastrous plague that afflicted it in 1656. Before that, it was the most populous town in Europe. A general renovation of the kingdom, compared with previous regimes, occurred with the instauration of the Bourbon family, which took place with the advent of Charles III in $1734 .^{5}$

A number of important plans were there developed and carried out, such as the building of new royal residences, public works, and factories. Such projects required the investment of considerable economic resources, which, in addition to the obvious architectural aspects, also solved important complementary problems, such as, for example, water supply. The architectural culture of the eighteenth century, indeed, acknowledged the relevance of hydraulic works, since their practical execution required high scientific and technical skills, and the Bourbons constantly favored, in the second half of the century, the updating of the competencies of technicians involved in the building of aqueducts, bridges, roads, and harbor works. ${ }^{6}$

One of the most important works of this epoch was the realization of the Acquedotto Carolino, planned to supply with water the Belvedere di San Leucio, a royal palace near Caserta. The realization of the Real Sito di Carditello, another royal estate built in the second half of the eighteenth century by Ferdinand IV (son of Charles III) near Capua to serve as a farmhouse, is far less famous, but equally important for the significant works of hydraulic engineering realized there. Although the architectural experimentation carried out by the technicians of the Bourbon House in Naples is well known, practically unknown is the story behind the realization of the water supply service for this Royal Palace. The key man who managed for such realization is as well not known, notwithstanding he was the very author of the introduction in the Kingdom of Naples (and, more in general, in 
Italy) of the most important technological innovation of that epoch-Watt's steam engine. His name is now recalled mostly by natural scientists (and few historians of physics), although Giuseppe Saverio Poli was one of the most influential figures of the Kingdom of Naples between the end of the eighteenth and the beginning of the nineteenth century. ${ }^{7}$ It was through Poli's agency that, as assessed in previous work, ${ }^{8}$ that the basic roots of scientific thought as well as technological innovations penetrated effectively (and enduringly) in the Kingdom of Italy.

The following describes in full detail this historical case, which is not at all known in the literature, although, quite curiously, it mimics in several respects what occurred in the Netherlands around the same time. ${ }^{9}$ The introduction in Italy of the technological prodigy of the eighteenth century-the steam engine-is usually dated to 1818, when the first steamship of the Mediterranean Sea was built in the renamed Kingdom of the Two Sicilies. However, as we will see, the steam engine was introduced in Naples just thirty years before that event, and the related story is a fascinating piece of the history of that kingdom, as well as a relevant piece of the history of Watt's steam engine.

The next section provides a short account on Giuseppe Saverio Poli, one of the protagonists of our story, pointing out his unique role in introducing the first fruits of the scientific and technological revolutions in the Kingdom of Naples. Following that is a brief summarize the milestones in the history of the steam engine, with particular reference to the work of Boulton and Watt, as also acknowledged by Poli. The intriguing story of Poli's engine is fully recounted in the subsequent sections, from its conception to its successful establishment, and beyond, since the story did not end with the engine's construction. The tragic epilogue, causing even the cancelling of the historical memory of such an episode, is finally highlighted in the final section, along with few other concluding remarks.

\section{The Perfect Scholar and the Man of Power}

Giuseppe Saverio Poli (figure 1) was born in the Apulian town of Molfetta on October 28, 1746. After completing his first studies at the local Seminario Diocesano, in 1765 Poli was sent to Padua, where he enrolled to study medicine with Leopoldo Marco Antonio Caldani and Giovanni Battista Morgagni, and had Antonio Scarpa as fellow student. He also pursued classical education with Jacopo Facciolati, becoming fluent in Greek, Latin, and French, and studied physics, astronomy (with Giuseppe Toaldo), botany, and natural history. After some stays in Venice, Ravenna, Bologna, Genova, Florence, and Rome, he came to Naples in 1771, where he earned his master's degree ("dottorato") in medicine; he also practiced for as a medical doctor until 1776, but then switched his attention to the study of natural sciences. Despite his degree, his scientific interests centered mainly on physics, with particular reference to contemporary debates about electricity. ${ }^{10}$ 


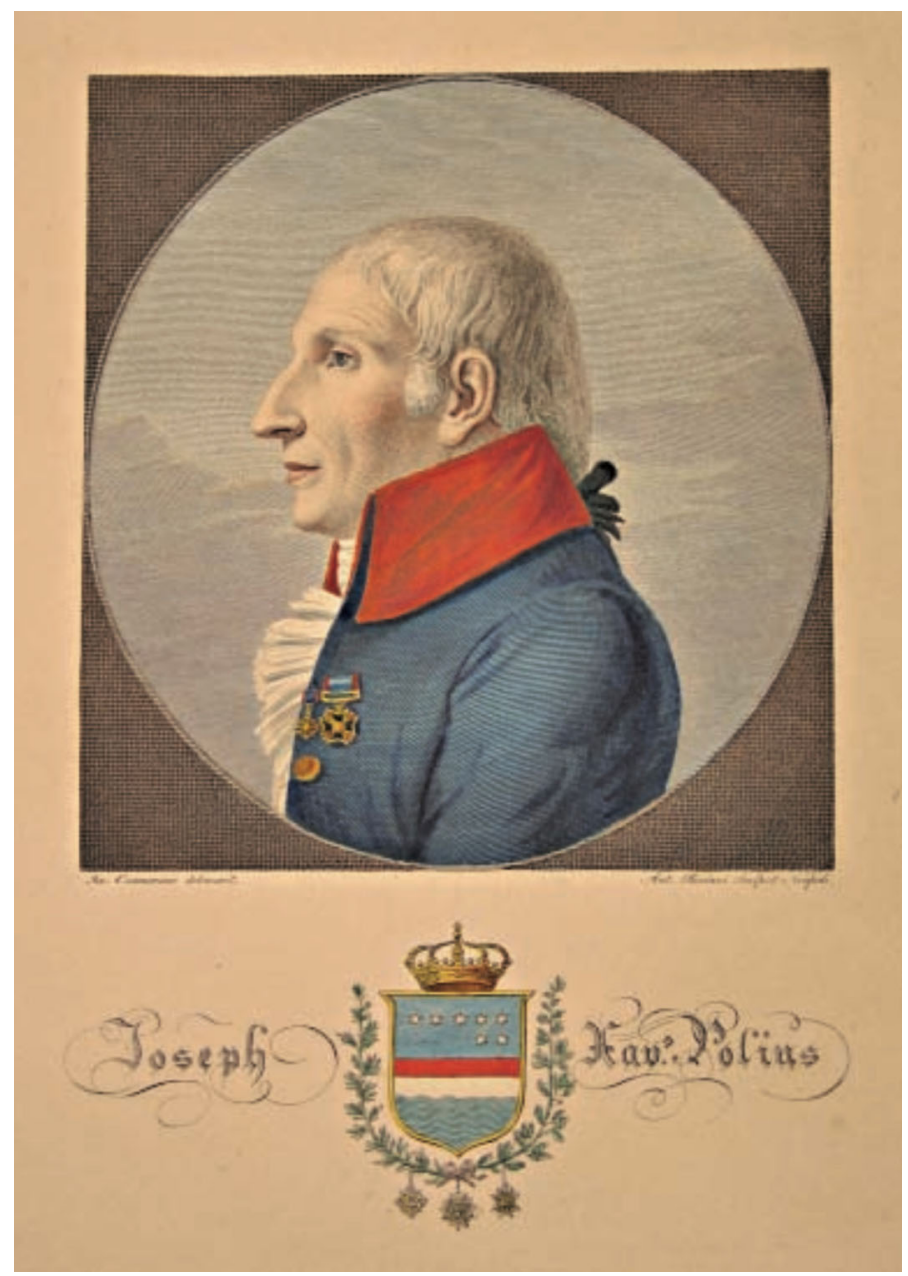

Fig. 1. Portrait of Giuseppe Saverio Poli. Source: Giuseppe Saverio Poli, Testacea Utriusque Siciliae eorumque Historia et Anatome tabulis aeneis illustrata. Tomus Tertius. Pars Prima Posthuma (Parma: Ex Ducali Typographeio, 1826).

In 1774 Poli was given the rank of Second Lieutenant and called to teach Geography and Military History at the Royal Academy of the Corps of Cadets (Reale Accademia del Battaglione Real Ferdinando, later Reale Accademia "Nunziatella"), created by Ferdinand IV of Bourbon by merging the old artillery academy with that of the engineers. Promoted to Lieutenant, Poli was then sent abroad to acquire instruments for the academy's scientific cabinet. He took this opportunity (1777-79) to visit the most important academies and institutes in Italy, Germany, France, England, and Holland, and to study mechanical application 
methods. In these countries, Poli received high recognition for his erudition, and his well-regarded works on electricity opened the doors of the major scientific academies of Europe to him. He was elected Fellow of the Royal Society of London in 1779: the honor to be a named home member of the society was reserved for very few non-British people. During his journey Poli naturally encountered the major physics instrument makers, such as Dollond and Ramsden, with whom he forged close relations not limited to his task to acquire scientific instruments for the Naples Academy.

Upon returning to Naples in 1780, Poli was appointed to the Chair of Physics at the Real Collegio Medico-Chirurgico at the Regio Ospedale di S. Maria del Popolo (Arcispedale degl'Incurabili) and taught experimental physics both at the Incurabili and at the Nunziatella. The textbook for the course of experimental physics, Elementi di Fisica Sperimentale composti per uso della Regia Università, was published in 1781 and indicates how, in teaching mechanics and other subjects, Poli adopted all manner of experimental demonstration devices. ${ }^{11}$ The clarity of exposition, along with an abundance of examples, made the fortune of this textbook, which counted-from 1781 to 1824 - a total of twenty-three new editions and reprints (and a posthumous reprint of 1837). It was the most widely used (Italian or foreign) textbook of physics in Italy between the end of the eighteenth century and the first quarter of the nineteenth. ${ }^{10}$

Notwithstanding the striking success of the Elementi, Poli's most important scientific contribution is the outstanding Testacea Utriusque Siciliae eorumque Historia et Anatome tabulis aeneis illustrate (Shelled animals of the Two Sicilies with their description and anatomy), on comparative anatomy and classification of mollusks in the Kingdom of the Two Sicilies. ${ }^{12}$ This work is widely recognized to have effectively laid the foundations of malacology, and was acknowledged by some of the major scientists of the nineteenth century, including Charles Darwin. ${ }^{13}$ Indeed, it was the first treatise on molluscan biochemistry and physiology, coming from the accurate experimental studies performed by the author, documenting in detail various aspects of shellfish morphology, and reporting a number of novel characters discovered by Poli himself.

In 1784, after a second diplomatic mission to Holland and Germany in the entourage of the Duke of Gravina, King Ferdinand selected Poli to tutor to the Crown Prince Francis I for his encyclopedic culture, one of many important court assignments. From that point, an indissoluble link with the Royal family was forged. Due to the events of the end of 1798, following the French invasion, the Bourbons were forced to take refuge to Palermo. Poli readily followed the royal family into exile. With the first restoration, however, after the brief period of the Parthenopean Republic (January-June 1799), Poli returned to Naples, and in 1803 he was nominated Commander of the "Nunziatella" Royal Military Academy.

Returning from his second exile in Palermo with the Royal Bourbon Court during the decade of French domination in the Kingdom of Naples (1806-15), he was elected member (and later, in 1819, became President) of the Reale Istituto 
d'Incoraggiamento alle Scienze Naturali (Royal Institute for the Encouragement to the Natural Sciences) in 1816. In 1820, following upheaval in the Kingdom aimed at establishing a constitutional monarchy, King Ferdinand I of the Two Sicilies was forced to create a constitutional parliament with democratically elected members. However, the King managed to stock the assembly with loyalists. On November 20 of that year, Poli became state councilor in the constitutional parliament. Just one year before his death, Poli was charged as Ufiziale alla immediazione di Sua Altezza Reale Francis I (official to the immediacy of His Royal Highness), following his beloved prince on his journeys throughout the kingdom. ${ }^{14}$ Poli died on April 7, 1825-at the age of 78-in his home in Naples.

\section{With the Eye of the Witness: The Powerful Steam Engine}

During his journey in England, the curious scholar Giuseppe Saverio Poli "discovered" the existence of the marvelous steam pump (named tromba a vapore or tromba a fuoco) - that is, a steam engine-based pump-whose description and functioning, along with its possible applications, was readily reported in his lectures on experimental physics delivered in Naples, and then incorporated in his textbook Elementi di Fisica Sperimentale:

It is termed steam pump since its working power is due neither to men nor animals, but rather to the steam coming from boiling water. Continually rising from a big boiler full of water placed above a small furnace, this steam penetrates into a pump, where alternatively produces vacuum and plenum.... Its applications and advantages are innumerable, since very great is its efficacy to raise any quantity of water to any height, as well as to provide mills and shipcanals with water, to dry lakes and marshes of any magnitude, to produce uninterrupted and regular motions in any direction. ${ }^{15}$

In contrast to other authors of science textbooks, Poli described what he saw with his own eyes-a feature that likely contributed to the great success of the Elementi. According to his account:

In the famous manufacture of the ingenious Mr. Boulton in the town of Birmingham there is a large number of devices working by means of such a pump, which also provides the water for a ship-canal. I saw those pumps in other Counties in England used in some foundries, in order to let huge blowing apparatuses working in iron furnaces. It is useful to know that the power of such an engine is completely unbounded, since it can be raised-in a sense-to infinity by increasing the proportions of its parts. It works day and night with no interruption and can be stopped at any moment very easily. ${ }^{16}$

Poli the eyewitness did not fail to realize that at the heart of such marvelous, different devices was the steam engine improved by the "incomparable Mr. Watt," and Poli the teacher did not miss the opportunity to let his students in Naples to 
see with their own eyes how such a technological prodigy worked, by means of a model built on purpose on his order:

The pump to raise water can be divided from what the English terms Steam Engine, consisting just in the cylinder-where we noticed the steam from the boiling water enters-from which the power of the engine develops. Then, by means of just such an engine and without the help of any water but that in the boiler, paper mills, grinding mills and any other device can work, sometimes with an infinite advantage, especially in countries poor of water. An excellent model of such an engine, built on my order, can be seen in the rich cabinet of our Royal Military Academy. By means of it, acting as a small grinding wheel, an appreciable quantity of water can be raised in a pump; as well, it can be used to work a mill that effectively grinds wheat, or scutches flax, or even can be used to act some hammers in a rolling mill. It has the advantage to be built with the latest improvements introduced by the incomparable Mr. Watt. ${ }^{17}$

As is well known, the Scottish James Watt was not the inventor of what effectively was the moving force of the Industrial Revolution, that is the steam engine-a heat engine performing mechanical work, using steam as its working fluid. ${ }^{18}$ But that what Watt conceived and constructed was a key component of paramount importance for the development of that revolution, since, as noted by Poli, it allowed factories operate in placed where waterpower was not easily available.

Interestingly enough, among the first studies concerning the possibility to exploit the motive force of heat we find those of Giovanni Battista Della Porta in Naples at the beginning of the seventeenth century. ${ }^{19}$ The Neapolitan scholar realized how the water contained in a tank could be pushed upwards by the steam pressure acting on its surface, the steam condensation being able to produce suction capable of drawing water from a lower level. Della Porta's intuitions and speculations about the steam elastic force, contained in the Tre libri de' spiritali, ${ }^{20}$ introduced to the scientific community the ideas that allowed the realization of the steam engine, which, not by chance, took place instead in England. The English technical skills for the production of water suction systems using the steam power became particularly advanced during the subsequent century, since the problem of drain the mines ducts appeared so frequently there.

Thomas Newcomen develop the first successful atmospheric steam engine using a piston by improving a previously patented (1698) fire engine by Thomas Savery. ${ }^{21} \mathrm{He}$ used it in 1712 to remove flood water from a mine. It was essentially designed for pumping: the vacuum created in it was used to suck water from the sump at the bottom of a mine or, more generally, to raise water from below. It was employed mainly for draining mine workings at depths hitherto impossible, as well as for providing reusable water supply to drive waterwheels in factories.

Watt's contribution was twofold. First, it enabled an engine of a given size to do more work with less fuel than the Newcomen engine, thus improving the power, efficiency, and cost-effectiveness of steam engines. Second, and more importantly, 
it widened the field of application of steam engines to a level that was impossible with earlier engines. This was accomplished by employing several devices able to convert the reciprocating motion of the piston to a rotary motion suitable for driving factory machinery, such as for grinding, weaving, and milling.

Watt's early engines used about half as much coal as the Newcomen engine (as improved by John Smeaton) but, notwithstanding the translation of his ideas into workable designs, a long time had to pass before Watt could construct a full-scale engine. ${ }^{22}$ The main reason was the need for capital. A partnership was imperative for him, as he continued to work toward perfecting his steam engine with costly experiments. ${ }^{23}$ The turning point came when the businessman Matthew Boulton began to correspond with Watt. ${ }^{24}$ Boulton realized that a steam engine could provide power for his Soho Manufactory in Birmingham. In 1774 Boulton convinced Watt to relocate. An engine was erected and satisfactorily run. The subsequent year, Boulton and Watt entered a partnership whose aim was no longer limited to producing power for the Soho Manufactory, but rather aimed at a profitable business venture for efficient steam engine production.

In 1776 the Boulton \& Watt firm began installing the first engines in commercial enterprises, beginning in Staffordshire and Shropshire. ${ }^{25}$ They were not typically manufactured by Boulton \& Watt; they rather purchased parts made by others according to drawings made by Watt, and then assembled on-site. Watt at first served as consulting engineer and supervisor in the erection of the engines: these were large machines, which required the construction of a dedicated building to house them. Only later, with the expansion of the Soho firm, did others take over construction and site management, allowing Boulton and Watt to remain in Birmingham. $^{26}$

In the subsequent years, Watt made many improvements and modifications to the steam engine, whose field of application greatly widened when in 1782 he was able (urged by Boulton) to convert the reciprocating motion of the piston to produce rotary motion, required in mills and factories. Further study and experimentation (especially on rotative beam engines) led Watt to another important technological innovation. By moving from single-acting pumping engines to double-acting ones, where steam was used to press alternately on the opposite sides of the piston, he enabled the engine to make a power stroke in both directions, without introducing an external force that would retract the piston. The project of a double-acting engine was effectively brought forward only in 1782-83 when considering rotative engines, with the further innovation of the so-called parallel motion device producing the straight-line motion required for the cylinder rod and pump from the connected rocking beam, whose end moves in a circular arc.

A number of other improvements, modifications and far more experimentation kept Watt busy for a long time, not only with purely technical problems, but also protecting the economic success to the enterprise with Boulton against patent infringements, piracy, and marketing problems. ${ }^{25}$ Even though Boulton \& Watt erected the first reciprocating, single-acting steam engine in the Continent as early 
as in 1780, the first rotative engine (outside Soho) in 1783 and the first doubleacting engine the following year, it was until 1788 that Watt was allowed to relax from business, being assured the success of his engine. What made this fact clear is, likely, not well known in the literature, and required the agency of an unexpected actor, as recounted in the following section.

\section{In Need of Watering the Royal Prairies of Carditello}

Always anxious to achieve a successful enterprise, Watt realized he had finally reached his goal when one of his engines was ordered from the King of Naples through Giuseppe Saverio Poli's intermediation. As reported in his Elementi:

[The engine] that I had built in England for the service of His Majesty our Most Clementant Sovereign, and which is already established near the fortresses of Capua to raise the waters of the River Volturno, to be able to water the Royal prairies and the fields of Carditello during summertime, has three feet in diameter, and is able to lift 500 cubic feet of water up to the height of 25 feet in the stretch of each minute; and consequently 30 thousand cubic feet in one hour time. Consider each one as an immense copy that raises it in the interval of 24 hours! $!^{27}$

The Royal Estate of Carditello (figure 2), near Capua, served as a farm for the use of Ferdinand IV of Bourbon, King of Naples. Its origins trace to 1745, when Charles III (Ferdinand's father) established a horse farm in the forests and marshes of the Real Difesa di Carditello. As noted by one Neapolitan historian, "Ferdinand IV called a not so large population [to Carditello] to attend the herds of cows, buffaloes and horse races, which he wanted there, and also to make good cheeses as in Lodi... There are also eight well-built big sheds for the people involved in the job. Finally, there was a forest of oaks, elves, and other wild trees, in which there are wild boars, goats, foxes and hares for King's hunting." 28

The works for Ferdinand's farm were completed in 1785, but soon the problem of irrigating the fields of the royal estate emerged, and Ferdinand IV did not hesitate to assign the problem to the reliable courtier and scientist Poli, who immediately thought of contacting an old acquaintance of his in England.

\section{Poli Meets Boulton}

As noted above, Poli visited England in the late 1770s, in search of instrument makers able to provide him with appropriate instruments for the Physics Cabinet of the Royal Military Academy in Naples, including the leading technician Jesse Ramsden. ${ }^{29}$ According to Boulton, Ramsden first introduced Poli to him, ${ }^{30}$ and on that occasion Poli talked with Boulton about a possible engine to be sent in Naples at the order of the King: "During my stay in England we [Boulton \& Poli] had a long conversation together about a fire Engine, that his Sicilian Majesty would 


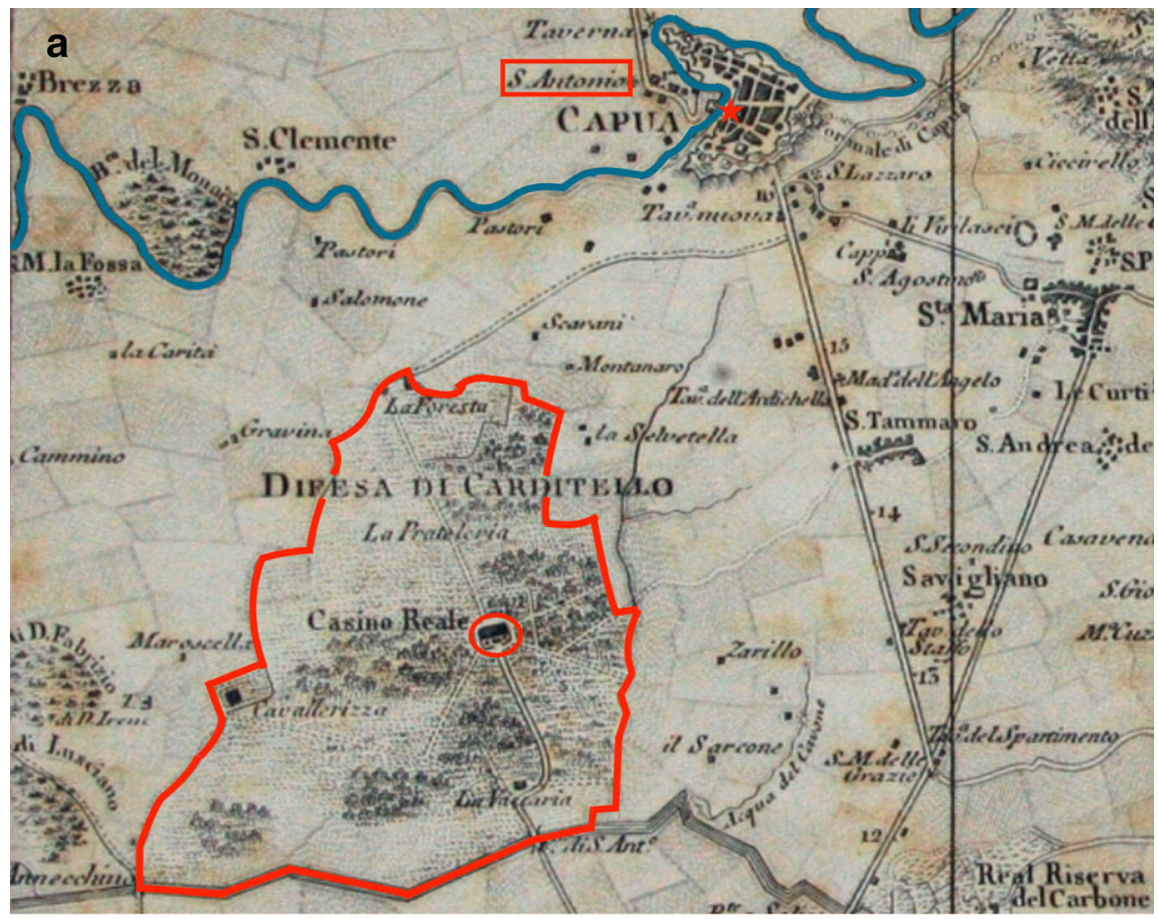

b

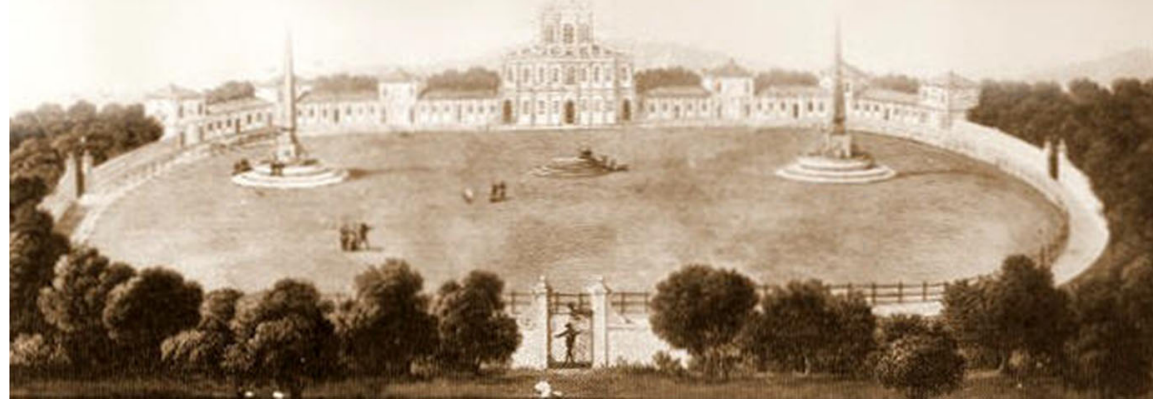

Fig. 2. The Royal Estate of Carditello. a) Map of the Real Difesa di Carditello from Rizzi Zannoni, “Atlante geografico del Regno di Napoli.” Source: Giovanni Antonio Rizzi Zannoni, Atlante Geografico del Regno di Napoli (Napoli: [s.n.], 1812). The house of Poli's Engine was erected on the river Volturno (highlighted in blue) near the town of Capua (Fortini di Capua; see the red star), not very far from the place where the Molini di S. Antonio were later built. b) A view of the Royal Palace (Casino Reale) of Carditello, from an ancient engraving. 
perhaps have settled at Naples.... You informed me further that an Engine capable to raise ten thousand cubic feet of water one foot high in one minute's time would cost one thousand Pounds besides the building, as it appears from the note you favoured me with." 31

Poli visited the Boulton \& Fothergill company in Birmingham in November or October 1779, accompanied by the Venetian Ambassador Simon Cavalli, who purchased some items. ${ }^{32}$ On that occasion, the two Italians had the opportunity to see some steam engines in the Soho Manufactory which, however, were still reciprocating single-acting pumping engines able, mainly, to extract water from the mines of the Cornwall. Nevertheless, Poli realized the usefulness of the engines, and Boulton did not fail to promote his products designed by Watt: "At Birmingham ... you were so good as to spend an evening there with me, and the Venetian Ambassador [Simon Cavalli]. There you set down all the dimensions, and prices of the Engine at large, with all the least particulars relating to it, so that it takes up a whole sheet of paper." 33

\section{Favorable Circumstances}

Despite the genuine interest in Watt's steam engine, at the time of Poli's trip to England in 1779-80 no "favorable circumstances" emerged for the King of Naples to acquire the technology. The situation changed when the Royal Palace at Carditello was completed. When the effects of the hot summertime of 1786 appeared, Poli promptly wrote to Boulton on behalf of King Ferdinand IV to order a steam engine able to irrigate the fields of the Royal Estate:

His Majesty being proposed of a meadow of a vast current within 15 miles from Naples; and being desirous to cover it regularly every year since the month of May till that of September, has thought proper to make use of a fire Engine, which might raise upon the water from the River Volturno, and dispose it by the means of several little canals through the meadow abovementioned: it seems to me that all the circumstances are favourable to his scheme, as the water is not to be raised any higher than 27 French feet in order to carry to such a point that is about five French feet above the natural level of the ground which wants watering. The side of the River, which being the nearest to the meadow is the proper place for settling the Engine, is about two English miles distant from the meadow itself. The bed of the River is very large there; and the height of its water during the summertime when the lowest of all, amounts to four English feet. At two miles distance from the place of the Engine there is a large forest, which might afford the necessary quantity of wood. ${ }^{34}$

King's order turned out to be compelling and, at the same time, Poli likely misinterpreted Boulton's early promotion, or misunderstood the difficulty in making and assembling a powerful steam engine. In fact, he ingenuously continued his letter to Boulton as follows: 
His Majesty will send two of his Frigates to England, perhaps about the month of September; and they shall remain there for some time. Therefore, orders will be given to their Captains to get you on board the ship the Engine and carry you to Naples, where you may depend to be very graciously received from his Majesty who is well acquainted with your great abilities; so that I am sure you will not repent to have undertaken such a voyage.

I will inform you Sir, that his Majesty will reward you for your trouble besides the cost of the Engine, and will grant you a Patent in case you wish to hire it. This, if I am not mistaken, was the particular condition you mentioned me to be assured of before your departure from England. So that I hope nothing will hinder you from getting the Engine ready as soon as possible. I am so sure you will comply with his Majesty's wishes, that I give myself the pleasure to wish you a good voyage.

The first problem was a foreseeable delay in Boulton's reading Poli's letter, which happened only at the end of September, exacerbated by the fact that Poli missed the appropriate recipient address (Chippindall's 119 Fleet Street in London, instead of Truro in Cornwall). Nevertheless, Boulton promptly informed Watt of the novel, distinguished request from Naples on September $26,{ }^{35}$ and just two days after he replied in order to let Poli realize the difficulty in designing and building an appropriate steam engine for the use required and, at the same time, to ask him to reconsider the proportions of the engine requested:

His Sicilian Majesty wishes to hire a New Engine of our invention erected near Naples of such power as to raise 10000 Cubic feet of water one foot high per minute; or say equal to the raising of 370 Cubic feet of water 27 feet high per minute which is more than three Millions of Cubic feet to work (for the Engine will work day \& night if required). This is a large quantity of water, to water meadows. I therefore want you to reconsider whether you really have use for so much.... These things I mention that you may see the real causes why I cannot so suddenly obey your summons \& go aboard the Frigate you mention... I will consult my partner Mr. Watt so soon as I return to Birmingham which will be about the end of October.... In the intron, please to let me know the extent of the Meadow you mentioned (in English measure) \& some particulars relative to the manner of watering it \& how many hours per day you want have of Engine to work. $^{36}$

Boulton's request for further details about the expected working of the steam engine pump for Carditello was dictated by the impossibility of making a preliminary on-site survey, but was likely prompted also by his and Watt's desire to meet in the best possible way the expectations of a client as illustrious as the sovereign of one of the most important kingdoms in Europe. The effect of such request on the passionate researcher Poli was that, in order not to give approximate and hypothetical answers, he performed an accurate experiment to determine the quantity of water required for the irrigation of Carditello's fields, 
thus providing Boulton and Watt with a detailed explanation of the power of the steam engine to employ. On February 27, 1787, Poli wrote:

The extent of the meadows is four hundred Moggios. One Moggio is 399906/7 English feet squares, and it contains 46656 Neapolitan Palms square, and one and 1/6 Neapolitan Palm measures one English foot.

The said 400 Moggios are to be divided in eight spots, each of fifty Moggios. One of these spots (that is 50 Moggios) is to be watered each day; so that all the 400 Moggios above mentioned shall be watered in eight days; and, of course, each spot of fifty Moggios shall be watered every fortnight.

The Engine is to work fourteen hours a day, as the watering cannot be done but from six in the evening to eight in the morning, the heat of the day not permitting its being continued any longer without hurting the product of the earth.

To give you an idea of the quantity of water, which is required for the said meadows I procured to get a standard in this manner. I have made my observations upon a little spot of land of the extent of five Moggios, which are watered once every fortnight; and having applied a large tube of about ten English Inches in diameter to the side of the Canal which leads the little stream employed to water the said five Moggios, I have occasioned all the stream to fall, through the said tube, into a cubical Receiver of 64 English cubic Feet, which was filled up in about 35 seconds of time. Now you must know that such a stream flows constantly during fourteen hours in order to water the five Moggios abovementioned: consequently, it will be required ten times as much water for the said fifty Moggios every day; or to say better eight time as much, allowance being made for the difference of the soil, which is not so bibulous, or spongy in the said 400 Moggios. Then you see Sir, what the Engine as mentioned, capable to raise 370 cubic feet of water per minute 27 feet high, is not sufficient for our purpose. However, His Majesty having been informed by me of all these particulars, told me that such an Engine will do very well; and that he does not want a larger one, as He intend to water so many Moggios only as showed want the quantity of water, which shall be raised by that Engine.

The water raised by the Engine will run about one mile through a canal made of masonry; and then it will be distributed to the several spots of land through other canals disposed in the plain ground, so that the water overflowing from them will water the meadows as above. ${ }^{37}$

As a courtier, Poli naturally kept King Ferdinand IV updated. He knew the king's predilection for the Reggia di Carditello. It would have been equally unsurprising for the beloved tutor of the young Crown Prince to involve his pupil in the determination mentioned, as a practice lesson for him. A further feature this situation, however, king's impatience to have the engine, which forced Poli to reiterate to Boulton the request for a prompt delivery, along with a new request for a skilled erector able to let the engine to work effectively and efficiently in a 
country where no trained technicians were available: "Our Frigates will sail for London next month in order to carry a present to His Britannic Majesty, and will stay there till the month of September. Therefore, His Majesty would wish that you was so good as to get ready the said Engine for that time, and put it on board the said Frigates. If you cannot come yourself with the Engine, you must absolutely send a person, who could set it at work, and instruct our people how to manage it at large; otherwise, it would be of no use, nobody here being acquainted with it." 38

\section{A Difficult Start: Ramsden Enters}

Notwithstanding the urgency Poli expressed, months passed without Boulton giving an answer, despite a new letter forwarded to him in May 1787 through the Neapolitan Ambassador in London. Summer then arrived without news from England about the engine for the King of Naples. On July 24, Poli wrote again to Boulton asking for a prompt response to his request, "His Majesty being very anxious to get such an Engine with the utmost speediness." Poli abandoned a professional tone and delivered a heartfelt appeal: "For God's sake, be so good as not to fail to forward it, as I promised to His Majesty that his order should be accomplished before the end of that year." 39 True to his Neapolitan style to leave no stone unturned, however, at the same time Poli sent also a letter to his old friend Jesse Ramsden in London, begging him to urge Boulton to answer. Ramsden, for its part, did not hesitate to take Poli's request into consideration, and on August 16 wrote to Boulton in Soho in a convincing manner:

I know very well the many engagements you have and how every moment of your time is employed in objects of the greatest importance, otherwise I should feel myself very much hurt as my own disappointment as you promised to call on me when you was in London, but I know you man of the world think is not necessary to keep any engagements with an old woman, but I would not have you be too sure that you'll get off so easily for I assure you there is only one way I will forgive you, which is to answer this letter as soon as possible. ${ }^{40}$

This was not the only action undertaken by Ramsden; he managed to meet Boulton when he came to London on September 20, where Boulton showed Ramsden a draft of a letter answering Poli, declaring that he could not send an engine to Naples before the subsequent spring. This was nevertheless a reassuring sign for Ramsden, and Boulton was induced to promise to finish and send the letter by the following Saturday, in order for Ramsden to forward it to Poli. Probably unexpectedly, on that Saturday Boulton did not come to Ramsden's workshop, but claimed he had been to the Neapolitan Ambassador in London without finding him in town, so that he could not have done anything on the business. At this point, knowing the need for Boulton to leave London for Cornwall the subsequent morning, Ramsden offered to personally deliver any 
message to the Ambassador, but Boulton declined the offer with the further promise "upon his honour" to write a letter to Poli and send it to Ramsden before he left London, "though he might be obliged to set up all night, being very engaged that day." Ramsden received no letter from Boulton, and no letter or message was collected by a servant of him sent two days later to Boulton's residence. Ramsden's last, dramatic action was to write on October 1 to Boulton threatening him to send an incendiary letter to Poli (enclosed in his own letter to Boulton) where all the efforts performed by him to induce Boulton to answer were described in detail:

I cannot forfeit my character nor the good opinion of my friends at Naples how as trifling you may think my application, be assured I will never give up my request till I can satisfy my friends that $I$ have not neglected their requests or the commissions that they have entrusted me with. I therefore take the liberty to enclose a copy of a letter I intend to send to Mr. Poli... I will wait fourteen days for your answer and if I do not receive any by that time I shall conclude you approve of it and I will send my letter to Naples by the next mail after. ${ }^{41}$

The fourteen-day ultimatum was, this time, not disregarded and, one week later, from Truro in Cornwall, Boulton at last answered to Poli, by apologizing for the long delay (partly due to his absence on business in France and, anyway, for his commitment to business), and reassuring the customer about his interest in the engine for the King of Naples: "I must therefore entreat you to endeavour to appease his Majesty \& to assure him that it is my greatest ambition to merit his approbation \& that I will not fail to fulfil his Majesty commands early in the approaching year." The best guarantee for his genuine interest was that, in the same letter, Boulton finally came fully into the matter, including the price of the engine:

I observe that you have made some experiments to determine the quantity of water wanted \& that the result of those experiments is you want to have 370 English Cubic feet of water raised 27 English feet high.... I am persuaded it would be more agreeable to the King to pay one sum for all I will tell you as near as I can what I think it would come to fix: The Castings of Iron of the Cylinder ... £ 1500; for Boulton \& Watt drawings, directions trouble \& various expenses \& for their profit, altogether without any annuity as in England $£ 1000$, to which you must add the Wages of one Man from the time he sets out to the time he returns at about 25 Shilling per week \& you must also add the freight to the place of its erection. ${ }^{42}$

At the same time, a memorandum was written by Boulton to Watt with the determination of the technical details for the "New Engine." 43 The business definitively started. 


\section{Poli's Engine for the King of Naples}

In that same letter, Boulton asked Poli for further details about the site where the engine was to be erected, in order to proceed in the best possible way for the preparation of the engine. Poli provided the required technical details in a letter dated November 26 (written in an understandably detached way), where he enclosed two plates containing the section and the plan of the river Volturno with the Royal Meadows at Carditello. "Now having before you both the Section of the River, and the general Plan of the whole, you may see how to settle the matter touching the water course to be open from the River to the bottom of the Pumps; how it must be constructed, and to what a distance from the River it should be extended." 31

Poli also provided a number of suggestions about where the engine could be erected, how the water of the river could be conveyed, where the canal could be built and directed, and so on. He got fully involved in the business, not only due to Boulton's request, but also for his own interest, which was only barely concealed behind the interest of the King: "You may set down your scheme at large upon the first Plate itself, and send it back again along with the Engine, or any other way you shall like the best. His Majesty wishing to be perfectly acquainted with the construction of the Engine in order to be able to judge by himself of anything relating to it, I beg you will send a full explanation of all its parts with the proper drawings annexed to it." 44 Probably, Poli's interest in the engine was twofold: on one hand, the curiosity of the scholar might have prevailed, but on the other hand, the teacher's diligence might have manifested once again, especially toward his young pupil, the Crown Prince Francis.

\section{Setting the Business}

A not at all a secondary issue, addressed in the same letter, was the economic one. Boulton requested a total of $£ 2,500$ for the engine to be built and for the profit for his and Watt's enterprise, but Poli pointed out that Boulton, when the two met in Birmingham years earlier, quoted a total price of just $£ 2,000$. Once again, the typical Neapolitan style came out:

The only thing I would have you to consider is, that since the infancy of my project to His Majesty I gave Him a paper written of your own hand at Birmingham, when you was so good as to spend an evening there with me, and the Venetian Ambassador. There you set down all the dimensions, and prices of the Engine at large, with all the least particulars relating to it, so that it takes up a whole sheet of paper. The King therefore being already acquainted with those particulars in the most solemn way, I beg you will consider with your knowledge, and prudence, if it is honourable for me to mention any alteration about the price of the Engine.... His Majesty will give you one thousand Pounds for its price when delivered on board; besides one thousand Pounds for your profit, 
drawings, directions, trouble, and various expenses; without any annuity, and any other advantages of any kind. Proper orders shall be given next week to the Neapolitan Ambassador in London, and you may apply to him for anything regards this subject.

In the first days of January 1788, the Neapolitan Ambassador in London, Count Lucchese, transmitted Poli's letter to Boulton, including the two plates mentioned above, and was officially appointed to take care of the business. Boulton then managed to see the Ambassador (finally succeeding in this only on the evening of February 4), with whom he tried to settle the economic affair true to his English style: "I know not what paper of particulars Mr. Poli alludes to which he says I gave him at Birmingham. I shall explain to the ambassador our usual terms \& shall agree to show him the Invoice before the Engine is sent off which he may then accept or reject. Moreover the Engine we then talked of was a 33 Inch Cylinder to the best of my memory. Kings and ministers are so used to be imposed upon that they suspect all men." 45

The issue was likely superseded by "all the dispatch possible" the Ambassador desired, so that Boulton was left with nothing to do but start the production of the engine, with Watt directly involved. Within months, the pieces required were ordered and produced, and by the end of May 1788 an extremely detailed invoice (figure 3) was provided to the Ambassador by the Boulton \& Watt company. ${ }^{46}$ The price to be paid for only "cast iron, hammered iron and brass materials" for the steam engine was about $£ 2,000$ : what Boulton envisaged earlier was evidently correct. Boulton "settled the plan" of payment with the Ambassador on May 29. ${ }^{47}$ One week later, the agent and banker of the Boulton \& Watt company, William Matthews was asked to "draw the Bill for the Ambassador to sign," which "will accordingly be done next week, and Matthews will send it to Laghorn for payment," 48 just in time before the engine embark for Naples.

The business, however, was still not settled. A number of troubles made their appearances. The most foreseeable ones regarded-of course-the carriage of the engine parts. On May 28, Boulton wrote to Watt from London that "Renney says the piston rod for Poli's Engine is ready, but there is no cap to it, as he says none was ordered," 49 while the day after: "I believe the things from Hull are arrived and beg Mr. Roberts may be ordered to send everything from Soho directly by the Wagon. If there is any not quite ready, let them be sent by flying Wagon afterwards." 50 On June 3, "neither the Goods from Chester nor Hull are yet arrived but I hope expect they will be in good time for the Ship that sails for Naples," 51 and on June 7, "neither of the Vessels are yet arrived from Gainsborough." The two Neapolitan frigates (likely, Minerva and Cerere) to be employed for the carriage of the engine, notably, had also another important task to complete (among the others), that is, transporting purebred horses purchased by King Ferdinand IV. ${ }^{52}$ This evidently explains the increase in concerns for Boulton \& Watt. 


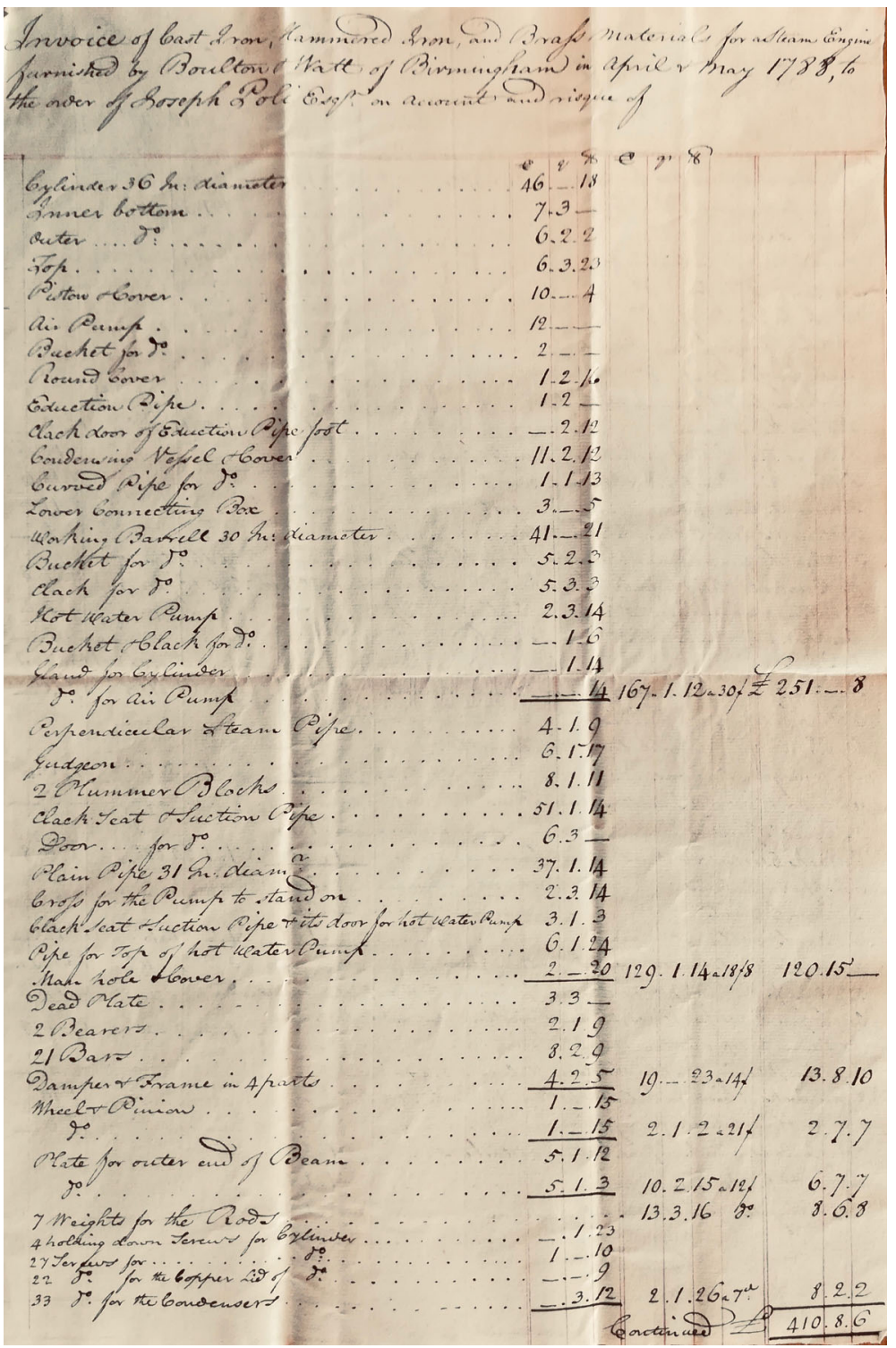

Fig. 3. "List of the articles belonging to Poli's Engine for the King of Naples," that is, Boulton \& Watt invoice for Poli's Engine (first page of four). Courtesy of The Library of Birmingham: Birmingham Archives and Heritage, Boulton \& Watt Collection.

A more interesting issue (for us) was, instead, that of the "drawings" of the engine, in which Poli was particularly interested, though hiding himself behind the 
presumed King's desire "to be perfectly acquainted" with the steam engine (see Figs. 4, 5, 6). Indeed, it is intriguing that both Boulton and Count Lucchese were unexpectedly anxious to deliver them to Naples with the engine. Of course, during the production and preparation of the different parts of the engine, the drawings prepared by Watt were owned by him, for whom it was quite usual to make changes and improvements until the very end, this being particularly true for an important order of the King of Naples. Boulton was aware of this habit, so that it is not surprising that on May 29 he wrote to his partner: "I and Mr. Matthews are engaged to dine with the Ambassador on Friday $6^{\text {th }}$ June viz tomorrow sevenight, and therefore you may keep the drawings a few days longer." Two days later, however, on May 31, kindness already gave way to anxiety: "Please to remember that I am engaged to dine with the Ambassador next Friday and Matthews also, where I will settle all money matters \& deliver the drawings." 53 Three more days later: "I hope the drawing will arrive time enough for me to keep my promise of presenting them to him on Friday when I am to dine with him." ${ }^{54}$ Fortunately for Boulton, he delivered all the drawings to the Ambassador in due time, keeping Watt informed of the outcome of the June 6 dinner. ${ }^{55}$

\section{A Double-Acting Engine}

As mentioned above, Poli's engine was designed by Watt, although it shared some standard features with other Boulton \& Watt engines of the same period. The engine was based on a double-acting cylinder, where the steam acted alternatively on both sides of the piston. It also included the parallel motion mechanism Watt devised for such engines, where a mechanical linkage with four bars coupled with a pantograph allowed the (approximately) rectilinear up-and-down motion of the piston rod to be transmitted to a beam moving in a circular arc. Nevertheless, Watt introduced some exceptional features to the engine he prepared for the King of Naples. $^{25}$

First, the working gear had an arbor for each steam, equilibrium, and exhaust valves, with the gears of these valves interlocked (figure 6). Specifically, the opening of the equilibrium valve was subject to the closing of the exhaust valve, and the opening of the steam and exhaust valves was subject to the closing of the equilibrium valve. The injection valve was independently worked. The steam and equilibrium arbors each had a detent adapted to engage a pivoted catch, each tending to turn in the direction to open its own valve by means of a weight suspended upon an arm projecting from it. Leather straps connected the tail of the top arbor detent catch to a lever on the equilibrium arbor and the tail of the equilibrium arbor detent catch to a lever on the exhaust arbor, while connecting another lever on the exhaust arbor to a lever on the top arbor.

When the equilibrium arbor rotated to close its valve, shutting off communication between the top and the bottom of the cylinder, the catch of the top arbor detent was released, the top arbor turning by means of a suspended weight to open 

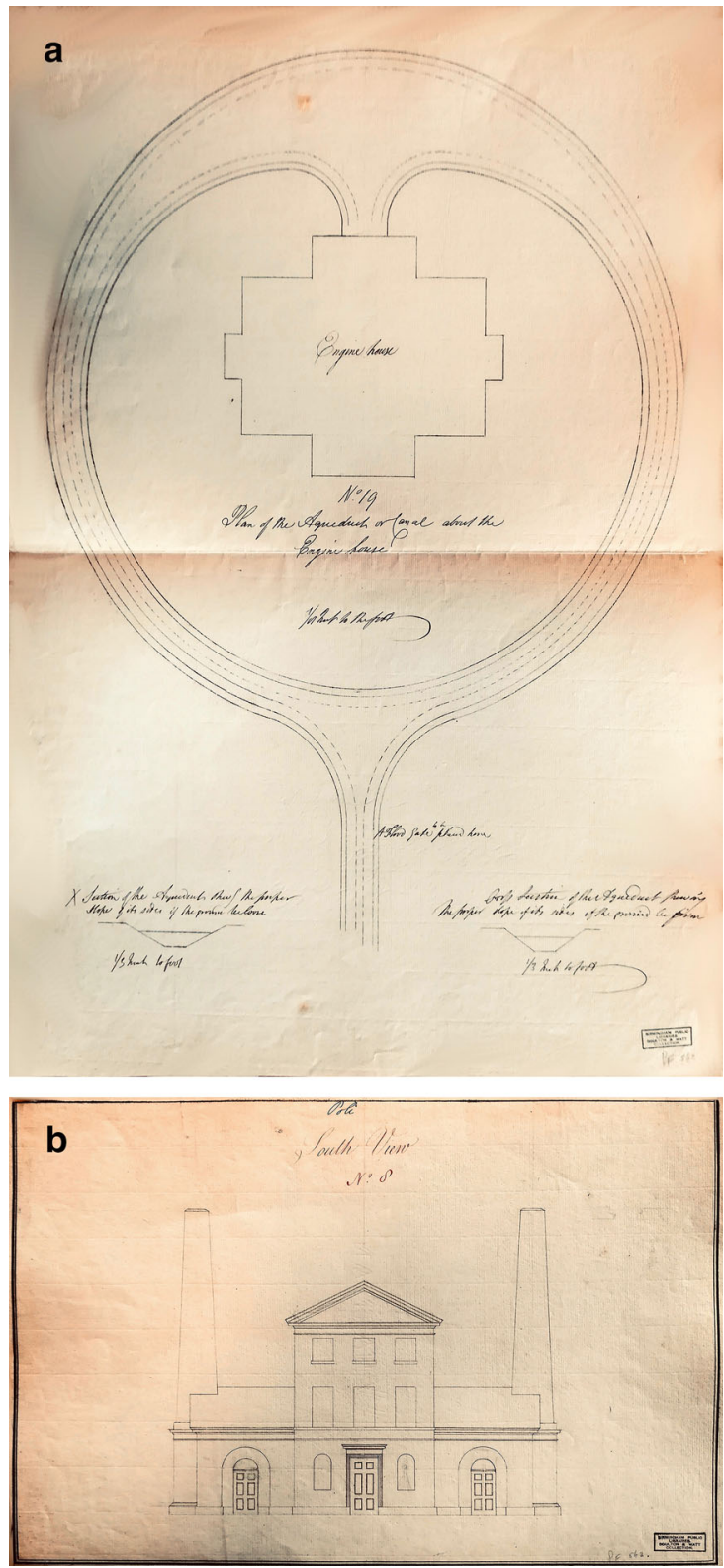

Fig. 4. House for Poli's Engine in Carditello. a) "Plan of the Aqueduct or Canal about the Engine house." b) South view of the Engine house. Courtesy of The Library of Birmingham: Birmingham Archives and Heritage, Boulton \& Watt Collection. 
its own valve and pulling round (through a strap) the exhaust arbor to initiate the movement of its valve. Such movement was completed by the steam pressure on its upper face, while the valve carried with it the exhaust arbor and the attached parts: in such a way, the top of the cylinder was in communication with the boiler and the bottom with the condenser, the downstroke of the piston ensuing. In the corresponding downward movement of the plug-tree, a chock acted upon the handling arm of the top valve, while another chock acted upon that of the exhaust valve (which were now in their raised positions), thus restoring them in the position shown in the figure with the top and exhaust valves shut. Instead, when the exhaust arbor rotated by means of a lever and a strap, pulled down the detent catch of the equilibrium arbor, this turning by means of the suspended weight to throw open the equilibrium valve for the up-stroke. As the piston ascended, a peg on the plug-tree engaged the lower side of a handling arm, raising it to close the equilibrium valve: with the arm restored to the position shown, it pulled a strap to disengage the catch of the top arbor detent for the downstroke.

Injection in the engine was worked by an arm and a rod: the valve was opened by means of a peg on the plug-tree on the underside of the arm, while closed-as the piston began to descend-by chock pressing upon its upper side. The equilibrium valve was opened when the corresponding arbor was released by the rotation of the exhaust arbor; the top gear was released to open the valve by the rotation of the equilibrium arbor, and the exhaust arbor was turned to start the opening of the exhaust valve by the rotation of the top arbor. Finally, each gear was restored to the position shown in the figure by the action of the plug-tree.

\section{Serving His Sicilian Majesty}

It was customary for Boulton \& Watt to send a trained technician to erect the engine when it became impossible for them to move from their headquarters. This issue was addressed as early as in January 1788, when the business of Poli's engine was definitively settled, and Boulton proposed sending one of their best collaborators to Naples: "I think [Malcolm Logan] is the prepared man we have to send to Naples as he is a handy fellow either in Wood or Iron or Engine or Mill or pumps." ${ }^{56}$ Logan was part of the squad of Scotsmen working for Boulton \& Watt since 1781, a mechanic of quick intelligence to whom Boulton refers as "a handy, active and industrious fellow." 25

\section{A Prepared Engine Man}

Unfortunately, the industrious Logan soon gave himself to drunkenness. When sent to a distance to fit up engines, mechanics were left in a great measure to themselves, so that some were apt to become careless and ill-conditioned. Notwithstanding this, in 1785 Boulton \& Watt entrusted Logan with the important task of erecting a steam engine (1785-87) for land drainage for the Batavian 

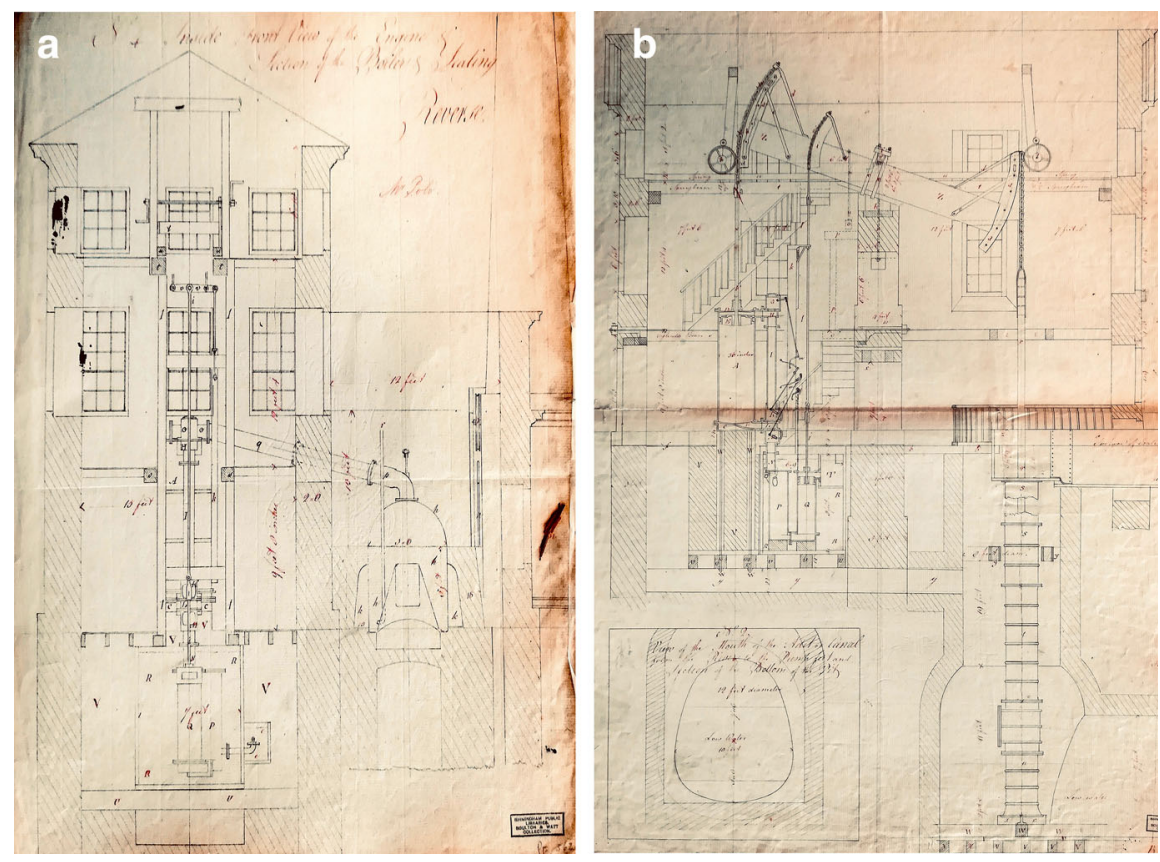

Fig. 5. Poli's Engine in Carditello. a "Inside Front View of the Engine \& Section of the Boiler's seating." b "N.1: General section"; "N.2: View of the mouth of the Aqueduct or Canal from the River to the Pump foot and Section of the Bottom of the Pit." Courtesy of The Library of Birmingham: Birmingham Archives and Heritage. Boulton \& Watt Collection.

Society in the Netherlands, although Logan's “disease" manifested itself also in this occasion. On February 24, 1786, Watt expressed his regret to Boulton, who appears as Logan's true sponsor: "I am very sorry to hear that Malcolm Logan's disease increases. I think you should talk to him roundly upon it, and endeavour to procure him to make a solemn resolution or oath against drinking for some given term." ${ }^{57}$ Nevertheless, Logan turned out to be a skilled mechanic, even able to make improvements to the original Watt's design and to demonstrate the power and flexibility of the engine erected on the Blijdorp polder in the province of Holland, for instance by shutting down the injection water for the condenser and letting the engine run for a couple of minutes "on the air pump." 58

Logan's experience in Holland was troubled for different reasons. Before the steam engine proved capable of flushing the Rotterdam canals, Watt wrote to the secretary of the Batavian Society—a savant-fabricant_-Jan Daniel Huichelbos van Liender in April 1787 that he "wanted to have dispatched Malcolm Logan but he told me that he was not yet quite able to go on account of a very dangerous fistula in and which he had almost died of." ${ }^{59}$ Watt was, indeed, "extremely vexed that M. Logan has not been able to set out sooner, as it deranges us in our business here, 


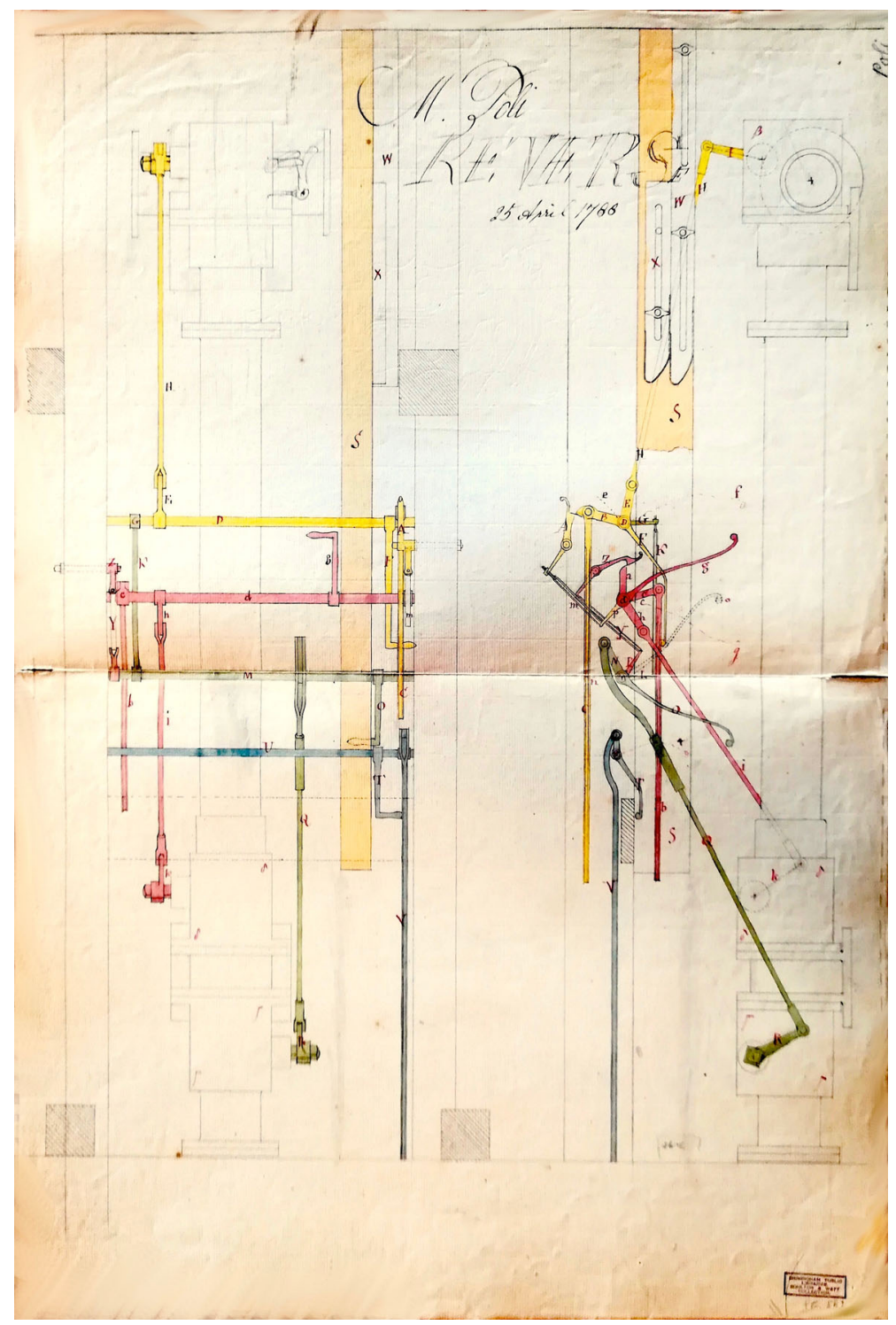

Fig. 6. Working gear for Poli's Engine, with the steam arbor (red), equilibrium arbor (green) and exhaust arbor (blue). Courtesy of The Library of Birmingham: Birmingham Archives and Heritage. Boulton \& Watt Collection.

having more to do than we have men to execute \& having few who are so fit for your business or any other which requires judgement as he is, though he be a 
drunken fellow he is honest \& ingenious." Later, in October of the same year, when the Dutch engine proved successful, van Liender wrote to Watt that he was "very well contented with his abilities, but I am sorry for himself, that he is so little master of his passions for that low vice of inebriety. He is quite addicted to it, and it will always prove his ruin; a great pity it is, that a man with such fine parts, is so much a slave of that misconduct." ${ }^{59}$ The same van Liender, however, proved to be not at all "sorry for himself" when, four years later, an experienced man was required for drainage at Meydrecht: he did come back to Watt, writing that "if Logan was returned from Naples, as he has been already once in Holland, I should think best to send him over, and if he is somewhat cured of his drinking fault, it would be so much better." 59

All these facts, if they induced Boulton to suggest employing the "honest \& ingenious" Logan to erect Poli's engine, likely prevented Watt from adhering enthusiastically to the proposal of sending a "drunken fellow" to serve the King of Naples. In May 1788 Watt proposed employing James Lawson rather than Logan, and this alternative offer was accepted by the Neapolitan Ambassador, as Boulton promptly informed Watt:

The Ambassador agrees to take Lawson upon the same terms as Logan via 25 per week \& pay his passage. I think is possible that Lawson may promote the Erection of Engines in the other Italian States but I think we should agree with him upon terms that may promote our interest as well as his non-otherwise not send him. I therefore wish you would talk with him before you consent to his going \& if you agree I then think it right that you should give him a Lesson upon Canal making as well as upon the minutia of the Erecting of the Engine. ${ }^{60}$

Alongside Logan, Lawson had been among the staff of engine erectors in Cornwall since 1782. Boulton's judgment that he could "manage the working of an engine better than any of their engine men" convinced the Count Lucchese to recruit Lawson instead of Logan. ${ }^{61}$ However, the Ambassador probably suspected some possible embarrassment in Naples due to this change of personnel and, just two days later, changed his mind in order avoid the ire of the King of Naples: "I have just received a message from the Neapolitan Ambassador saying that upon looking over his Letters etc. he finds it would be improper for him to send Lawson." ${ }^{62}$ Watt was not pleased by such intrusion, but the diplomatic Boulton readily realized that insisting on this point would have been inappropriate, and that "if we do it will be upon our risk and must rest upon the honour of the King, which is very precarious." ${ }^{63}$ On June 24 the Boulton \& Watt Company prepared a letter to be presented to Poli by the technician Malcolm Logan when he arrived in Naples:

In consequence of your obliging correspondence with our M. Boulton, we have prepared \& delivered to His Excellency Count Lucchese's order in London, a steam Engine Cylinder of 36 inches diameter, a suitable pump, a boiler \& condenser \& all the other cast Iron, hammered Iron, Brass \& Copper apparatus 
necessary to complete the Engine. We have also delivered to His Excellency a complete set of drawings \& directions for the erection, which we hope will sufficiently explain the structure of the House. We have sent all the expedition in our power, yet it has been with difficulty that we have been able to complete \& fetch the materials here by this time. We have made every part complete as far as could be done here $\&$ are certain there is no article of importance which have been omitted to be sent, though perhaps some small articles may have been neglected, as it is impossible to recollect or to have lists of all the minutia of such an Engine. We send this by Malcolm Logan an experienced workman who have erected many Engines is ingenious \& intelligent \& are expected well do his business to His Majesty \& your satisfaction. It has been with great difficulty we have prevailed with him to go so far from home but doubt not of his exerting himself to complete the business quickly \& well. He has been employed in collecting \& helping to ship the Goods from the beginning of last weeks, at which period we agreed with him that his services to His Sicilian Majesty should commence. ${ }^{64}$

\section{Striking Success in Naples}

Notwithstanding Logan's skill, the erection of Poli's engine required more than a year, due to varied, though typical technical problems. But at last both the functioning of the engine and Logan's work on it were very well appreciated. The credit company (operating in Naples) of the merchants Charles Cutler and Christian Heigelin, who were correspondents from the Bourbon capital of numerous English citizens, on September 1790 duly informed Boulton \& Watt that Logan gave "great satisfaction in his situation here, and of which His Majesty has given frequent testimonies" and, even more relevant for the two businessmen, that "he also wishes to have your answer about the Steam Engines, as he says 1 or 2 more will be wanted." 65

We do not know who requested the new engines, but, after the completion of the erection of the Poli engine, Logan was asked by the general manager of the Bourbons, Saverio Guarini, to prepare hydraulic engines for the Molini di S. Antonio (St. Anthony Mills; see figure 2) on the Lagno maggiore river. This mill was intended to grind cereals grown on the Carditello's estate using eight wheels, two on the ground floor and six on the upper floor, driven by hydraulics ${ }^{66}$ The building of the new mill was approved by King Ferdinand IV on July 17, 1792, but, some time before, another steam engine was requested from Boulton \& Watt to be erected in Spain, ruled by the same Bourbon family. In June 1792 a blowing engine arrived in Cadiz, as agreed by Boulton \& Watt with the Spanish naval officer Fernando Casado de Torres who, as early as June 1788, suggested to the Spanish Navy a proposal for a fire engine intended to work a sawmill in the Arsenal de La Carraca ${ }^{67}$ That proposal was probably independent of Poli's request to Boulton \& Watt, but it is remarkable the coincidence that the final contract was stipulated in 
1790, when Poli's engine finally revealed its success; the Cadiz engine arrived in Spain in 1792.

An erector was also required in Cadiz, and Boulton \& Watt again chose Logan for this task, convinced that his presence in Naples was no longer essential. Boulton, however, probably foresaw some possible obstacle to extracting Logan, due to his success in Naples, and on July 4, 1792, wrote a letter to Poli requesting his intervention to help Logan leave Naples, by using any forms of persuasion at his disposal:

I want request the favour of your good offices with his Majesty Ministers or any be proper to allow Malcolm Logan to leave Naples \& go by the first Ship to Cadiz in Spain where we have delivered a Steam Engine for the use of his Catholic Majesty. When Malcolm hath erected this Engine, he may return again to Naples in case he is wanted. We fear we shall disappoint his Catholic Majesty unless Malcolm is allowed to depart \& go by the first Ship to Cadiz which I beg you will accelerate by every means in your power. If I can render you any services in this Country I shall be happy to have it in my power. ${ }^{68}$

To be on the safe side, the following day he wrote to the powerful English Ambassador in Naples, William Hamilton, asking his personal "interference" in the affair (but including the letter to Poli): "We are unwilling to send another man there.... We wrote Malcolm a fortnight ago, \& now write to him again this day \& enclose to him a letter of introduction \& Credit to a Merchant in Cadiz. If any difficulty or obstruction to his departure should arise I must request the favour of your kind interference both in regard to the Neapolitan Government or any other that may impede his departure by the first Ship for Cadiz."69

On July 31, Hamilton promised Boulton that "no pains of mine shall be spared to serve you," and, if he discouragingly pointed out that Logan "is looked upon here as a very great man and they increase his pay daily to induce him to remain here," nevertheless prudently informed Boulton as well that "I know he has instructed a Mr. White in what relates to the Engine which makes me hope that they may let him go."70 Notwithstanding Hamilton's intervention, many months passed without success. On February 21, 1793, James Watt Jr., who was traveling to Italy, informed his father that Logan had once again delayed his departure for Spain in order to finish his work on the mill at Carditello. ${ }^{71}$

Indeed, an actual problem arose for the effective working of the Molini di S. Antonio, since the driving force provided by the Lagno maggiore river proved insufficient to operate the six millstones on the top floor of the mill simultaneously, forcing the operators to use them alternately. Logan was asked (along with Francesco Collecini and Carlo Pollio, among others) to consider that problem, which was referred to a technical commission appointed to evaluate the possibility of introducing water from neighboring rivers. ${ }^{72}$ Notwithstanding this, around March 1793 the Mill in Carditello was completed, and Watt Jr. (who, in the meanwhile, had met Logan) wrote to his father about his optimism concerning 
Logan's leave for Spain. It is interesting to note how the Neapolitan authorities conspired on that occasion to delay (or even avoid) Logan's departure, as described by Logan himself:

The King called for all my Letters, with an intention to write immediately to you, requiring your consent to my staying here, and for send me some other person in place. The Letter you addressed to the Intendant of the Marine at Cádiz, they also had from me and have never returned it me must therefore has the favour of you not to omit favouring me with another Letter for the Intendant.... It is necessary Gentlemen I should acquaint you, that the Leave the King has given me for going on your Business to Cadiz is on Condition of my having given my Word \& promise to return here as soon as your Business there be completed. Everything that depends on me, you may confidently rely on being executed with the greatest attention, and in such a manner as shall do Honour to their Employers, to you and myself. ${ }^{73}$

In January 1794, Logan finally departed for Spain, where he found a disastrous situation. The steam engine components that had arrived in 1792 showed signs of deterioration because of the humidity and the poor conditions in which they had been stored. A new location also had to be found for the engine, since the original location proved to be unsuitable due to a lack of solid foundations. Some time after Logan's arrival, in 1795, there a quantity of important pieces of the steam engine and the saw mechanism were stolen, so that both were incomplete and unable to work. The technician and Spanish officer Casado de Torres tried to replace the stolen pieces, but without success. However, these were not the only problems for Logan to keep at bay, given the renewed urgency of the Neapolitan Government who pawed to get him back in Naples, as recounted by Logan himself in a letter to Watt:

I have been called on by the Neapolitan Consul by order of the Minister at Naples to know for what case I stayed so long. The following is the copy of a letter I sent to him as I was ordered to write to him: ... "I have been unluckily detained a great deal longer than I expected owing to a variety of unforeseen Accidents the principal of which is caused by a mistake committed long before I came in the foundation of a Building destined for the reception of an Engine I was to put use in the [Carraca] and which renders it absolutely necessary to begin the work anew before I can proceed any further in the Business, and my chief motive for wishing to stay and complete the same is the regard I have for my former Employers and Manufacturers of the Engine who would think their Reputation injured were it not to be properly finished, but as my greatest Desire is to return to Naples as soon as ... I have order to that effect and permission from the Court of Spain." 74

The need to have the expert technician in Naples was genuine, as well as Logan's "greatest desire to return to Naples," but this last one was perhaps due to 
a reason not reported in the letter above, but rather in another one written by Casado de Torres to Boulton \& Watt in order to inform the English Manufacturers of the situation in Cadiz:

When I received your letter of December 24 I handed over the task to the Intendant of this Department to ask the Court of Naples to extend Malcolm's leave; and I know that the negotiation is opened by means of the Ambassador, and even I believe that there will be no difficulty in obtaining it. Despite everything I have told you about Malcolm Logan the day before yesterday morning, they say that he would leave us without completing the work, and that he would go away immediately if we did not give him the 14 guineas per month that was given to him in Naples. Well, Gentlemen, to that crass insult from Malcolm we replied that we would give him 14 guineas a month, and then he hit us with a knife to the throat. You have, therefore, your Malcolm Logan with 14 guineas a month, with accommodation, wood, water, serving, and in the end with everything he asked for: but will he still be happy? I do not think so. ${ }^{75}$

For one reason or another, Logan stayed in Spain less than two years, and eventually came back to Naples, where more works for the mills in Carditello were awaiting him. The Bourbon government did not miss the opportunity to have a good, qualified mechanic at their disposal to improve more and more the conditions of the Kingdom of Naples, along with its prestige.

\section{Conclusions}

The story of the introduction to Italy, through the Kingdom of Naples, of the most important technological innovation of the eighteenth century, Watt's steam engine, has a depressing ending, especially for the history of the Kingdom of Naples. Indeed, "the great fire engine of 3 feet in diameter erected on the Volturno river near Capua, which raised 30 thousand cubic feet of water per hour to 25 feet high, thus feeding a canal extending to Carditello to irrigate those campaigns" was destroyed "for the disorders of 1799," "76 when the Parthenopean Republic was established during the French Revolutionary Wars, after King Ferdinand IV fled before advancing French troops. James Watt was informed by his son Gregorywho in mid-1801 set off on European travels in hopes of recovering his health, then becoming a geologist and mineralogist-about what happened during those days, leaving some hope to reestablish the destroyed engine:

The country people have carried off everything from the engine at Caserta except the cylinder and pumps and they even attempted to blow up the [engine] house. All this will need renovation and when the King returns in a few weeks it will be set about and Malcolm Logan will send an order to you and demand a list of prices. Of course, if anything is done it will have unexceptionable security, for the Kingdom of Naples is ripening for Hell. ${ }^{77}$ 
Unfortunately, contrary to Gregory Watt's hopes, the first steam engine in Italy was not restored, and the acclaimed mechanic Malcolm Logan ended tragically his days, dying in indifferent circumstances shortly after the French invasion of the Kingdom of Naples in $1806 .^{78}$ As a contradiction that is often repeated in history, the Republican rebels of 1799, who asked the Bourbons for an improvement in their living conditions, saw in that technological progress only a value to be cannibalized immediately. As a consequence, even the historical memory of this first attempt at technological modernization of the Kingdom of Naples was soon lost, and this explains the absence of such an important episode also in history textbooks. These constantly report, indeed, that the first application of the steam engine was realized in Italy only thirty years later, when the Neapolitan shipyards in Vigliena built the first steamship, honoring the same King who introduced the steam engine in Carditello: the Ferdinando I sailed from Naples on a maiden voyage to Genoa and Marseilles on September $27,1818 .{ }^{79}$ It was no joke of fate that, steam propulsion was again introduced in the Kingdom of Naples, the first in the Mediterranean. Indeed, as in a letter to Boulton \& Watt by the Sardinian Minister, Marquis Grimaldi (who was the catalyst for such an introduction):

There is no Country like the Two Sicilies that offers many advantages for the employment of Steam-boats: both in the Adriatic and Mediterranean the navigation can be performed coast-ways, as well as from Naples to Sicily and Palermo, the coasts not being rugged, and presenting various landing places. The Company likewise enjoys the exclusive privilege of providing whatever Steam-engines might be required for Manufactories and Mills, in the two Kingdoms; many of which would be necessary as several Provinces from want of water are obliged to send their oil to be pressed and their corn to be grown at Naples: when once the steamengines were introduced many Manufactories would be established, and the steam-engines might at the same time be employed in the Mills. ${ }^{80}$

This is, however, story to be told elsewhere, which apparently did not benefit from the intervention of Giuseppe Saverio Poli. Nevertheless, although the architect of the realization of the first steam engine in Italy was de facto not directly involved in the realization of the first steamboat in the Mediterranean, it would be unwise to exclude any role of his even in such further technological improvement of the Kingdom of Naples. Still in 1817 (and even later) Poli's influence on King Ferdinand was evident, especially when concerning science and technology. This was only marginally due to his friendship with his former pupil, the Crown Prince Francis, while resting on his fame as a solid scientist and a reliable manager, as well as on his devotion to the Bourbons, whose major manifestation in that period was in his life chairmanship of the Reale Istituto d'Incoraggiamento alle Scienze Naturali.

Though not belonging to that densely inhabited network of entrepreneurial engineers that swarmed the second half of the eighteenth century, Poli nevertheless drove productive circulation of both knowledge and innovation in Europe, with significant results obtained in Italy and, especially, in the Kingdom of Naples. 
His activity and ability in spreading scientific knowledge, as well as in fostering technological innovation derived from it, was not at all unique in Europe-and, to a certain extent, he learned from his associates abroad-but it proved to be crucial for his country, and more generally for Italy. Poli fully embodied the Enlightenment ideals of utility and progress and was able, by means of his relationship with the Bourbon court, to translate those ideals into practice, a shining example of this having been recounted in the present work. Just as people throughout Europe continuously looked to England for inspiration, the Kingdom of Naples closely followed Great Britain in developing the modernization of the state. This happened, however, with the simultaneous "discovery" by the English and others of an immense and little known cultural and natural heritage, including Roman and Greek ruins, the marvelous Mount Vesuvius, Sicily, and so on, that called for the Grand Tour across the Kingdom of Naples. The lesson learned by historians recognizes the crucial importance of tending to regional specificities and differences, even when accounting for the history of industrialization. In this respect, Poli's engine was just one example of that British industrialization that relied on global interconnections among people, products, and processes. ${ }^{81}$

The beneficial effects produced by Poli's promotion of science in his country (and even abroad, through his published works) endured well beyond his death and brought a deserved fame to the Kingdom of the Two Sicilies as the most technologically advanced state in Italy, and one of the most influential one in Europe. The Bourbons were not so far-sighted to extend such benefits to any social class of their Kingdom, and the destruction of the first steam engine in Carditello was a painful example of that politics, which produced-in the present case - the erasure of the historical memory of that technological prodigy.

\section{Acknowledgements}

The present work was stimulated some years ago by Roberto Mantovani and Giuseppe Saverio Poli IV: my sincere thanks are here graciously expressed. I am also indebted to Andrea F. Scalella and Giovanna P. Perdonà for their invaluable help in archival searches. The very precious collaboration of the staff of the Birmingham Central Library (Birmingham), British Library (London) and Biblioteca Nazionale "Vittorio Emanuele II" (Naples) is kindly acknowledged as well.

\section{Funding}

Open access funding provided by Università degli Studi di Napoli Federico II within the CRUI-CARE Agreement.Open Access This article is licensed under a Creative Commons Attribution 4.0 International License, which permits use, sharing, adaptation, distribution and reproduction in any medium or format, as 
long as you give appropriate credit to the original author(s) and the source, provide a link to the Creative Commons licence, and indicate if changes were made. The images or other third party material in this article are included in the article's Creative Commons licence, unless indicated otherwise in a credit line to the material. If material is not included in the article's Creative Commons licence and your intended use is not permitted by statutory regulation or exceeds the permitted use, you will need to obtain permission directly from the copyright holder. To view a copy of this licence, visit http://creativecommons.org/licenses/by/4.0/.

Publisher's Note Springer Nature remains neutral with regard to jurisdictional claims in published maps and institutional affiliations.

\section{References}

${ }^{1}$ Lissa L. Roberts, "Full Steam Ahead: Entrepreneurial Engineers as Go-Betweens during the Late Eighteenth Century," in The Brokered World: Go-Betweens and Global Intelligence, 17701820, ed. Simon Schaffer, Lisa L. Roberts, Kapil Raj, and James Delbourgo, 193-238 (Camden, NJ: Science History Publications, 2009); "Geographies of Steam: Mapping the Entrepreneurial Activities of Steam Engineers in France during the Second Half of the Eighteenth Century," History and Technology 27, no. 4 (2011), 417-39.

${ }^{2}$ Lissa L. Roberts, "Water, Steam and Change: The Roles of Land Drainage, Water Supplies and Garden Fountains in the Early Development of the Steam Engine," Endeavour 24, no. 2 (2000), 55-58.

3 Roberts, "Geographies of Steam" (ref. 1).

${ }^{4}$ Roberts, "Full Steam Ahead" (ref. 1).

5 Benedetto Croce, Storia del Regno di Napoli (Milano: Adelphi, 1992).

${ }^{6}$ Riccardo Serraglio, "L'Acqua Carolina per l'approvvigionamento idrico di insediamenti produttivi e centri urbani," in Napoli-Spagna: architettura e città nel eighteenth secolo, ed. Alfonso Gambardella, 347-59 (Napoli: Edizioni Scientifiche Italiane, 2003).

7 Salvatore Esposito, "Giuseppe Saverio Poli e lo sviluppo della scienza tra la fine del Settecento e l'inizio dell'Ottocento," Rendiconti dell'Accademia Nazionale delle Scienze detta dei XL - Memorie e Rendiconti di Chimica, Fisica, Matematica e Scienze Naturali 1, no. 2 (2020), 125-39.

8 Salvatore Esposito, "Enlightenment in the Kingdom of Naples: The Legacy of Giuseppe Saverio Poli through Archive Documents," in Proceedings of the 36th Annual Congress of the Italian Society of the Historians of Physics and Astronomy, ed. Salvatore Esposito, 33-52 (Pavia: Pavia University Press, 2017).

${ }^{9}$ Lissa L. Roberts, “An Arcadian Apparatus: The Introduction of the Steam Engine into the Dutch Landscape,” Technology and Culture, 45, no. 2 (2004), 251-76.

${ }^{10}$ Esposito, "Giuseppe Saverio Poli" (ref. 7).

${ }^{11}$ Giuseppe Saverio Poli, Elementi di Fisica Sperimentale (Napoli: Fratelli Raimondi, 1781).

${ }^{12}$ Giuseppe Saverio Poli, Testacea Utriusque Siciliae eorumque Historia et Anatome tabulis aeneis illustrata. Tomus Primus (Parma: Ex Regio Typographeio, 1791); Testacea Utriusque Siciliae 
eorumque Historia et Anatome tabulis aeneis illustrata. Tomus Secundus (Parma: Ex Regio Typographeio, 1795).

13 Ilya Tëmkin, "At the Dawn of Malacology: The Salient and Silent Oeuvre of Giuseppe Saverio Poli," in Natural Histories: Extraordinary Rare Book Selections from the American Museum of Natural History Library, ed. Tom Baione, 69-72 (New York: Sterling, 2012); Salvatore Esposito, "Darwin and the Others: The Reception of Poli's Testacea outside Italy and Other Recent Discoveries about the Molfetta Scientist," in Proceedings of the 37th Annual Congress of the Italian Society of the Historians of Physics and Astronomy, ed. Benedetta Campanile, Lucia De Frenza, and Augusto Garuccio, 34-58 (Pavia: Pavia University Press, 2019).

14 Esposito, "Darwin and the Others" (ref. 13).

15 Giuseppe Saverio Poli, Elementi di Fisica Sperimentale, vol. 3 (Venezia: Tipografia Pepoliana, 1794), 150. Translation from the Italian by the author.

16 Poli, Elementi (ref. 15), 150-51.

${ }^{17}$ Poli, Elementi (ref. 15), 151-52.

${ }^{18}$ Henry Winram Dickinson and Hugh Pembroke Vowles, James Watt and the Industrial Revolution (London: The British Council, 1948).

${ }^{19}$ Paolo Piccari, Giovan Battista Della Porta. Il filosofo, il retore, lo scienziato (Milano: Franco Angeli, 2007).

${ }^{20}$ Giambattista Della Porta, I tre libri de' spiritali (Napoli: Iacomo Carlino, 1606).

21 David S. Landes, The Unbound Prometheus: Technological Change and Industrial Development in Western Europe from 1750 to the Present (Cambridge: Cambridge University Press, 1969).

22 Louis C. Hunter and Lynwood Bryant, A History of Industrial Power in the United States, 17801930, vol. 3, The Transmission of Power (Cambridge, MA: MIT Press, 1991).

${ }^{23}$ Henry Winram Dickinson and Rhys Jenkins, James Watt and the Steam Engine: The Memorial Volume Prepared for the Committee of the Watt Centenary Commemoration at Birmingham 1919 (Oxford: Clarendon Press, 1927).

24 Jim Andrew, "The Soho Steam Engine Business," in Matthew Boulton: Selling What All the World Desires, ed. Shena Mason, 63-70 (New Haven: Yale University Press, 2009).

25 Dickinson and Jenkins, James Watt (ref. 23).

26 Andrew, "Soho Steam" (ref. 24).

27 Poli, Elementi (ref. 16). The news was also reported in various Italian journals starting from 1795 , probably taken just from Poli's Elementi.

${ }^{28}$ Lorenzo Giustiniani, Dizionario Geografico Ragionato del Regno delle Due Sicilie (Napoli: Manfredi, 1797).

29 Anita McConnell, Jesse Ramsden (1735-1800): London's Leading Scientific Instrument Maker (Aldershot: Ashgate, 2007).

30 "Mr. Poli is a Gentleman that was first introduced to me by Ramsden who made him a philosophical apparatus at his Sicilian Majesty expenses." Matthew Boulton, letter to James Watt, September 26, 1786, The Library of Birmingham: Birmingham Archives and Heritage. Boulton \& Watt Collection (hereafter BWC), MS 3147/3/10.

31 Joseph Poli, letter to Matthew Boulton, November 26, 1787, BWC, MS 3147/3/518/N09.

32 “L'on m'a remis les petits articles, que avec M.r Poli j'avoir choisi, et je me suis mis en règle avec M.r Mattheus, mais j'aurais souhaité d'y trouver aussi les boutons d'acier, selon l'échantillon, que j'avoir mis de côté, fond uni, avec un contour de clous, et un groupe au milieu, avec du violet, 
pout habit, veste, et coulotte; et je vous prie de donner vos ordres, afin qu'ils me soient envoyés, et fans le même tems un cabaret de figure ronde, grand pour un service à thé, de vernis violet, quelque figure au milieu, et avec le contour d'argent plated." Simon Cavalli to Matthew Boulton, 29 November 1779, reported in G. Zorzanello, "L'inedita corrispondenza del diplomatico veneziano Simon Cavalli con Matthew Boulton (1779-1786)," Archivio Veneto 122 (1984), 35-64.

${ }^{33}$ Poli, letter Boulton, November 26, 1787 (ref. 32).

${ }^{34}$ Joseph Poli, to letter Matthew Boulton, July 4, 1786, BWC, MS 3147/3/518/N01.

35 "We would furnish him with an Engine to raise 400 Cubic feet of water 27 feet high for his Majesty and pay us for the Engine but will make us a handsome reward \& the offering to grant us a patent, also the King hath sent this month 2 Frigates to London \& Mr. Poli desires I would return in one of them \& bring the Fire Engine with me, \& a workman to erect it." Matthew Boulton, letter to James Watt, September 26, 1786, BWC, MS 3147/3/10.

${ }^{36}$ Matthew Boulton, letter to Joseph Poli, September 26, 1786, BWC, MS 3147/3/518/N02.

${ }^{37}$ Joseph Poli, letter to Matthew Boulton, February 27, 1787, BWC, MS 3147/3/518/N03.

${ }^{38}$ Poli, letter to Boulton, February 27, 1787 (ref. 37).

${ }^{39}$ Joseph Poli, letter to Matthew Boulton, July 24, 1787, BWC, MS 3147/3/518/N05.

40 Jesse Ramsden, letter to Matthew Boulton, August 16, 1787, BWC, MS 3147/3/518/N06.

${ }^{41}$ Jesse Ramsden, letter to Matthew Boulton, October 1, 1787, BWC, MS 3147/3/518/N07

${ }^{42}$ Matthew Boulton, letter to Joseph Poli, October 8, 1787, BWC, MS 3782/12/6.

${ }^{43}$ Matthew Boulton, letter to James Watt, n.d., BWC, MS 3147/3/518/N04.

${ }^{44}$ Poli, letter to Boulton, November 26, 1787 (ref. 31).

${ }^{45}$ Matthew Boulton, letter to James Watt, February 1, 1788, BWC, MS 3147/3/12.

${ }^{46}$ Boulton \& Watt Invoice, n.d., "List of the articles belonging to Poli's Engine for the King of Naples-Invoice of Cast Iron, Hammered Iron, and Brass materials for a Steam Engine furnished by Boulton \& Watt of Birmingham in April and May 1788, to the order of Joseph Poli Esq. on account and risque of." BWC, MS 3147/3/518/N10.

${ }^{47}$ Matthew Boulton, letter to James Watt, May 29, 1788, BWC, MS 3147/3/12.

${ }^{48}$ Matthew Boulton, letter to James Watt, June 7, 1788, BWC, MS 3147/3/12.

${ }^{49}$ Matthew Boulton, letter to James Watt, May 28, 1788, BWC, MS 3147/3/12.

${ }^{50}$ Matthew Boulton, letter to James Watt, May 29, 1788, BWC, MS 3147/3/12.

${ }^{51}$ Matthew Boulton, letter to James Watt, June 3, 1788, BWC, MS 3147/3/12.

${ }^{52}$ Boulton, letter James Watt, May 29, 1788 (ref. 50).

${ }^{53}$ Matthew Boulton, letter to James Watt, May 31, 1788, BWC, MS 3147/3/12.

${ }^{54}$ Boulton, letter to Watt, June 3, 1788 (ref. 51).

${ }^{55}$ Boulton, letter to Watt, June 7, 1788 (ref. 48).

${ }^{56}$ Matthew Boulton, letter to James Watt, January 25, 1788, BWC, MS 3147/3/12.

${ }^{57}$ Samuel Smiles, Lives of Boulton and Watt (London: John Murray, 1865).

${ }^{58}$ Jan Adrianus Verbruggen, "The Correspondence of Jan Daniel Huichelbos van Liender with James Watt" (PhD thesis, University of Twente, 2005). See also Roberts, "An Arcadian Apparatus" (ref. 9); Dickinson and Jenkins, James Watt (ref. 23).

${ }^{59}$ Verbruggen, "Correspondence of Jan Daniel Huichelbos" (ref. 58).

${ }^{60}$ Boulton, letter to James Watt, May 29, 1788 (ref. 52). 
${ }^{61}$ Dickinson and Jenkins, James Watt (ref. 23). About the choice of the man to be sent to Naples, the businessman Boulton was probably more concerned with promoting the interests of the company than with selecting a skillful technician, as evident from the letter quoted.

${ }^{62}$ Boulton, letter to James Watt, May 31, 1788 (ref. 53).

${ }^{63}$ Boulton, letter to James Watt, June 3, 1788 (ref. 51).

${ }^{64}$ Boulton \& Watt Company, letter to Joseph Poli, June 24, 1788, BWC, MS 3147/3/518/N11.

${ }^{65}$ Cutler \& Heigelin, letter to Boulton \& Watt, September 11, 1790, BWC, MS 3782/12/35/162.

${ }^{66}$ Serraglio, "L’Acqua Carolina" (ref. 6).

${ }^{67}$ Juan Helguera Quijada, "Transferencias de tecnologia britanica a comienzos de la revolucion industrial," in Estudios de Historia de las Tecnicas, la Arqueologia industrial y las Ciencias, ed. Juan Luis García Hourcade, Juan Manuel Moreno Yuste, and Gloria Ruiz Hernández, 89-106 (Segovia: Junta de Castilla y Leon, 1998).

${ }^{68}$ Matthew Boulton, letter to Joseph Poli, July 4, 1792, BWC, MS 3782/12/37/114.

${ }^{69}$ Matthew Boulton, letter to William Hamilton, July 5, 1792, BWC, MS 3782/12/37/117.

${ }^{70}$ William Hamilton, letter to Matthew Boulton, July 31, 1792, BWC, MS 3782/12/37/141.

${ }^{71}$ Boulton \& Watt, letter to Fermin de Tastet \& Co., March 25, 1793, BWC, MS 3147/5/592.

${ }^{72}$ Serraglio, "L'Acqua Carolina" (ref. 6). This project was initially supported by the Neapolitan government but, later, was blocked, because it was considered harmful for the cultivation of hemp and flax.

${ }^{73}$ Malcolm Logan, letter to Boulton \& Watt, December 31, 1793, BWC, MS 3147/3/395.

${ }^{74}$ Malcolm Logan, letter to James Watt, January 28, 1795, BWC, MS 3147/3/415.

75 "Lorsque je reçus votre lettre du 24 Décembre je passai office à M. l'Intendant de ce Département pour qu'il sollicita de la Cour de Naples de proroger le congé de Malcolm; et je sais que la négociation est ouverte par le moyen de l'Ambassadeur, et même je crois qu'il n'y aura pas de difficulté pour l'obtenir. Malgré tout ce qui je viens de vous dire de présenta avant hier matin Malcolm Logan en dissent qu'il nous laisserait sans achevés l'ouvrage, et qu'il s'en irait tout de suite si nous ne lui donnions les 14 guinées par mois qu'on lui donnait à Naples. E bien, Messieurs, a cet insulte grossier de Malcolm nous avons répondu que nous lui donnerai les 14 guinées par mois, puis qu'il nous métrait le couteau à la gorge. Vous avons, donc, votre Malcolm Logan avec 14 guinées par mois, avec sur logement, bois, eau, servant, et en fin avec tout ce qu'il a demandé: mais sera t'il content encore? Je crois que non." Fernando Casado de Torres, letter to Boulton \& Watt, June 3, 1795, BWC, MS 3147/3/421. Translation by the author.

${ }^{76}$ See the Rapporto generale sulla situazione delle strade, sulle bonificazioni e sugli edifici pubblici dei Reali domini (General report on the situation of roads, drainage, and public buildings of the Royal domains) in the Giornale del Regno delle Due Sicilie, May 3, 1827.

77 Gregory Watt, letter to James Watt, May 27, 1802, reported in Hugh S. Torrens, "The geological work of Gregory Watt, his travels with William Maclure in Italy (1801-1802), and Watt's 'proto-geological' map of Italy (1804)," in The Origins of Geology in Italy, ed. Gian Battista Vai and W. Glen; E. Caldwell (Boulder, CO: The Geological Society of America, 2006).

${ }^{78}$ James Watt Jr., letter to Arthur Oughterson, January 10, 1807, reported in Jennifer Tann, "Marketing Methods in the International Steam Engine Market: The Case of Boulton and Watt," The Journal of Economic History 38, no. 2 (1978), 363-91.

${ }^{79}$ Claudio Ressmann, "La prima nave a vapore del Mediterraneo," Rivista Marittima, February 2007.

${ }^{80}$ Marquis de Grimaldi, letter to Boulton \& Watt, March 25, 1817, BWC, MS 3147/3/439. 
81 Thomas Misa, Leonardo to the Internet: Technology and Culture from the Renaissance to the Present (Baltimore: Johns Hopkins University Press, 2004).

Istituto Nazionale di Fisica Nucleare, Naples' Unit, Complesso Universitario di Monte S. Angelo

Via Cinthia

80126 Naples, Italy

e-mail: salvatore.esposito@na.infn.it 